\title{
EVALUATING THE CENTER OF GRAVITY OF DISLOCATIONS IN SOCCER PLAYERS WITH AND WITHOUT RECONSTRUCTION OF THE ANTERIOR CRUCIATE LIGAMENT USING A BALANCE PLATFORM
}

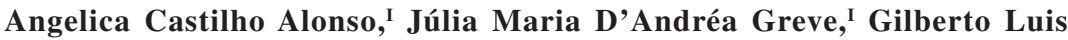 \\ Camanho II
}

doi: 10.1590/S1807-59322009000300003

\begin{abstract}
Alonso AC, D'Andréa Greve JM, Camanho GL. Evaluating the center of gravity of dislocations in soccer players with and without reconstruction of the anterior cruciate ligament using a balance platform. Clinics. 2009;64(3):163-70.
\end{abstract}

OBJECTIVE: The objective of this study was to compare the dislocation of the center of gravity and postural balance in sedentary and recreational soccer players with and without anterior cruciate ligament (ACL) reconstruction using the Biodex Balance System (BBS).

METHOD: Sixty-four subjects were divided into three groups: a) soccer players who were post- anterior cruciate ligament reconstruction; b) soccer players with no anterior cruciate ligament injuries; and c) sedentary subjects. The subjects were submitted to functional stability tests using the Biodex Balance System. The instability protocols used were level eight (more stable) and level two (less stable). Three stability indexes were calculated: the anteroposterior stability index, the mediolateral stability index, and the general stability index.

RESULTS: Postural balance (dislocation) on the reconstructed side of the athletes was worse than on the side that had not undergone reconstruction. The postural balance of the sedentary group was dislocated less on both sides than the reconstructed knees of the athletes without anterior cruciate ligament injuries. There were no differences in postural balance with relation to left/right dominance for the uninjured athletes and the sedentary individuals.

CONCLUSION: The dislocation of the center of gravity and change in postural balance in sedentary individuals and on the operated limb of Surgery Group are less marked than in the soccer players from the Non Surgery Group and on the non-operated limbs.

The dislocation of the center of gravity and the change in postural balance from the operated limb of the soccer players is less marked than in their non-operated limbs.

KEYWORDS: Proprioception; Postural balance; Soccer; Anterior cruciate ligament/surgery; Balance/evaluation.

\section{INTRODUCTION}

Balance is defined as the process that maintains the

'Laboratory for Motion Study, Instituto de Ortopedia, Faculdade de Medicina da Universidade de São Paulo - São Paulo/São Paulo, Brazil.

"Knee Group, Instituto de Ortopedia, Faculdade de Medicina da Universidade de São Paulo - São Paulo/São Paulo, Brazil.

Tel.: 5511 3069-7812

Email: angelicacastilho@msn.com

Received for publication on July 23, 2008

Accepted for publication on October 10, 2008 center of gravity within the body's support bases. It requires constant adjustments with muscular activity and articular positioning. Many nervous and musculoskeletal system diseases can alter balance control. ${ }^{1-3}$ Maintaining postural balance requires sensorial detection of the body's movements, integration of sensory-motor information into the central nervous system, and an appropriate motor response. The position of the body in relation to space is determined by the visual, vestibular and somato-sensitive functions. Muscular control and dynamic maintenance of 
balance involve the activity of coordinated muscular kinetic chains. $^{2,4-6}$

The anterior cruciate ligament (ACL) is responsible for $50 \%$ of all ligamentous knee injuries. The majority of injuries occur during sports activities, particularly those sports that involve movements of deceleration, rotation and jumping. These injuries occur predominately in males and are more common in the third and fourth decades of life. ${ }^{7,8}$ Soccer is the sport with the highest incidence of ACL injuries. ${ }^{8-10}$ The proprioceptive neurophysiological function of the ACL is important for its biomechanical role in the maintenance of joint stability. , $^{71-14}$

Mechanical stability can be successfully recovered after injury to the ACL through reconstructive surgery. However, the restoration of sensory and motor function remains controversial. ${ }^{11}$

Evaluating postural balance indicates deficiencies (mainly proprioceptive) and determines the efficiency of rehabilitation after injury or after reconstructive surgery.

The Biodex Balance System (BBS) is an instrument that analyzes dislocation of the center of gravity and postural balance by assessing the capacity to maintain dynamic postural stability on an unstable surface. ${ }^{15-19}$

The objective of this study was to compare the dislocation of the center of gravity (CG) and postural balance in sedentary and recreational soccer players with and without reconstruction of the ACL using the BBS.

\section{METHODS}

The study was performed at the Institute of Orthopedics and Traumatology, Hospital das Clinicas da Faculdade de Medicina, Universidade de São Paulo and at HCor (Heart Hospital) through approval granted by the Ethics Committee of the University of São Paulo (number 013/02).

Sixty-four subjects were divided into three groups: a) soccer players with ACL reconstruction, called the Surgery Group; b) soccer players with uninjured ACLs, called the Non-surgery Group; and c) sedentary individuals, called the Sedentary Group. The common inclusion criteria were: male gender, 20 to 40 years of age and absence of systemic disease.

The Surgery Group consisted of 24 individuals, aged $29 \pm 6$ years (20-40), height $175 \pm 8.5 \mathrm{~cm}(165-188)$ with an average body mass of $79.6 \pm 8.5 \mathrm{~kg}(65-96)$. The inclusion criteria were: a) reconstructive surgery of the ACL, with unilateral involvement, and autograft of the patellar tendon, with or without associated injuries for at least 18 months; b) resumption of soccer playing for at least 10 months; c) playing recreational soccer two or more times per week; d) no surgery on the contralateral limb; e) no episodes of instability after surgery; f) no other surgery of the lower limbs; and g) no limitation of joint movement $\geq 15^{\circ}$ of flexion. Thirteen $(54.16 \%)$ athletes had had an operation on the right knee, and $11(45.83 \%)$ had had an operation on the left knee; $14(58.33 \%)$ had undergone surgery of the dominant limb (defined as the leg for kicking), and 10 $(41.66 \%)$ had surgery on the support limb; 11 (45.83\%) had associated injuries to the meniscus; and 23 individuals were right-handed. The mean time between surgery and evaluation was 36 \pm 10 months (minimum: 21 months; maximum: 59). Thirteen (54.16\%) athletes played on a soccer field, $12(50 \%)$ played on an indoor soccer field, and seven (29.16\%) played on a futsal field; eight (33.33\%) played two modalities of soccer. The mean time of rehabilitation was $6 \pm 6$ months (2-20 months), and the time to return to sport was $10 \pm 3$ months (6-20 months).

The Non-surgery Group comprised 20 subjects, aged $26 \pm 6$ years (20-38), mean height $179 \pm 0.05 \mathrm{~cm}$ (170-186), with an average body mass of $74.9 \pm 13.0 \mathrm{~kg}$ (46-107). The inclusion criteria were: a) no surgery or injury of the lower limbs; b) playing recreational soccer two or more times per week; and c) clinical tests negative for knee instabilities. Seven $(35 \%)$ athletes played on a soccer field, $12(60 \%)$ played on an indoor field, $11(55 \%)$ played on a futsal field, and $10(50 \%)$ played two modalities of soccer. In 17 persons (85\%), the right limb was dominant, and the left limb was dominant in three $(15 \%)$.

The Sedentary Group consisted of 20 subjects with a mean age of $26 \pm 5$ years (20-38), a mean height of $171 \pm 0.03 \mathrm{~cm}(169-175)$, and a mean body mass of $71.8 \pm 8.7$ $\mathrm{kg}$ (58-87). The inclusion criteria were: a) no physical activities for at least six months; and b) no surgery on or injury to the lower limbs. In 17 persons (85\%), the right limb was dominant, and in three (15\%), the left limb was dominant.

The balance test was carried out using the BBS by the same evaluator for all groups. Stability varies according to the resistance level (where level eight is the most stable and level one is the least stable). ${ }^{2,20-23}$ The instability protocols used were level eight (more stable) and level two (less stable). Level two allowed an inclination of up to $20^{\circ}$ in the horizontal plane in all directions. Three stability indexes were calculated: anteroposterior, mediolateral and a general stability index (sum of the first two).

\section{Positioning}

The patients were positioned barefoot on the platform, supported on one foot, with the corresponding knee semiflexed at a $10^{\circ}$ angle. The contralateral knee remained flexed at a $90^{\circ}$ angle. The patients crossed their arms over 




Figure 1 - The Biodex Balance System

their chests and looked at the screen in front of them. The platform was released, and the patients were instructed to balance themselves with the indicator kept at the center of the target on the screen. When the patient was capable of achieving a balanced position without hand support, the foot position was recorded using the platform rail (Figure 1).

Once the subjects had been positioned, they were instructed not to move their feet until the end of each measurement. Changes were recorded in relation to the center of the platform. The tests were initiated at level eight. Three 20 -second measurements, separated by oneminute intervals, were made on each leg, and then the same procedure was repeated at level two. The results are given as the arithmetic mean of the three measurements, which is supplied automatically by the equipment. The Surgery Group started the tests with the operated limb, and the Non-surgery Group and Sedentary Group started with the dominant limb.

\section{Statistical analysis}

The statistical analysis for intragroup comparisons (operated side versus non-operated side) was performed using the Wilcoxon test for non-parametric samples. The statistical analysis for dominant versus nondominant limb was carried out using a Student's paired $t$-test for parametric samples and the Wilcoxon test for non-parametric ones. The intergroup comparison used a Student's non-paired $t$-test for parametric samples and the Mann-Whitney U-test for non-parametric ones. In all tests, a significance level of 0.05 $(5 \%)$ was used.

\section{RESULTS}

The groups were similar in age and height, with a significant difference in body mass (as determined by the Tukey test $(p=0.027))$ between the sedentary group and the uninjured athletes.

There were no significant differences in the dominant limb between the uninjured athletes and the sedentary group, so their data were grouped for the purpose of statistical comparison (Table 1).

The operated side (OS) of the Surgery Group presented less dislocation of the center of gravity and greater stability when compared with the non-operated side (NOS) for all indexes of stability at level eight (Table 1). The OS of the Surgery Group presented less dislocation of the center of gravity and greater stability for all indexes of stability at level two when compared to the Non-surgery Group.

There were no significant differences between the NOS in the Surgery Group and either the dominant or nondominant side of the Non-surgery Group (Table 2).

The OS in the Surgery Group presented more dislocation and less stability for all indices of stability when compared with the Sedentary Group at level two. The NOS presented more dislocation and less stability for all indices of stability at levels eight and two when compared with the Sedentary Group (Table 3).

The sedentary group presented less dislocation and greater stability in all indices of stability at levels eight and two when compared with the Non-surgery Group. (Table 4).

\section{DISCUSSION}

Evaluating postural balance is important in joint injuries for making treatment decisions such as the type of surgery and the rehabilitation results. ${ }^{21}$ Tests must reproduce the functional activities and measure the postural balance across the vestibular, visual and neuromuscular control systems. ${ }^{21}$ Information on postural balance can be used to plan specific exercises to enhance proprioceptive control and prevent falls. ${ }^{3}$ This study used the BBS system because it is very simple and easy to use and can provide quick, quantitative measures of postural balance, center of gravity dislocation, 
Table 1 - Intragroup comparison of the center of gravity dislocation and postural balance in the Surgery Group (OS versus NOS), Non-surgery Group (DS versus NDS), and Sedentary Group (DS versus NDS) at stability levels 8 and 2

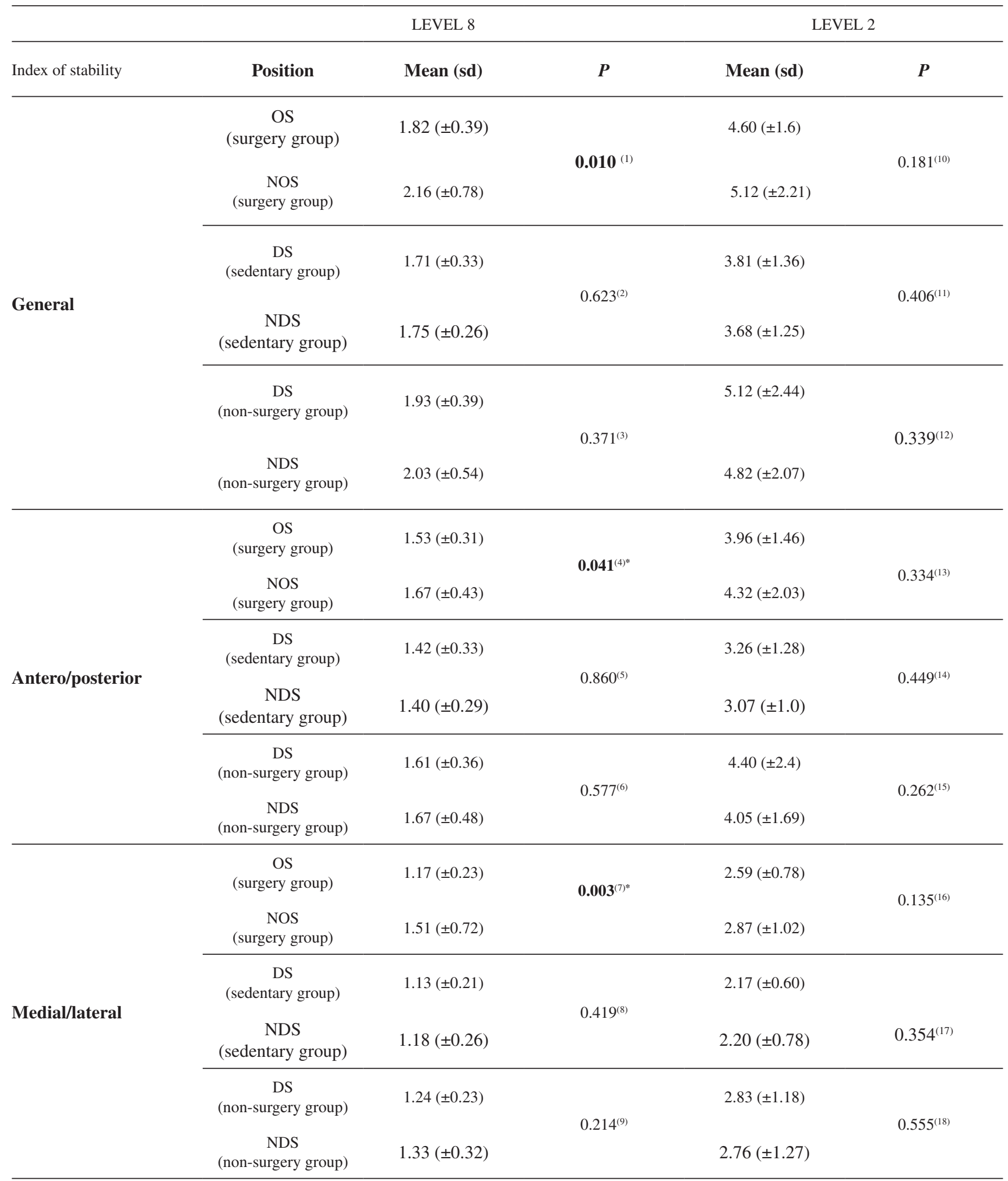

[ (1) (2) (4)(5)(7)(8)(10)(12)(13)(15)(16)(18) Wilcoxon's test; (3)(6)(9)(11)(14)(17) Student "t" test] * $p \leq 0.05$

$\mathrm{OS}=$ operated side $; \mathrm{NOS}=$ non-operated side $; \mathrm{DS}=$ dominant side, $\mathrm{NDS}=$ non-dominant side 
Table 2 - Intergroup comparison of the center of gravity dislocation and postural balance of the Surgery Group (OS and NOS) versus the Non-surgery group (DS and NDS) at stability levels 8 and 2

\begin{tabular}{|c|c|c|c|c|c|}
\hline \multirow[b]{2}{*}{ Index of stability } & \multicolumn{3}{|c|}{ LEVEL 8} & \multicolumn{2}{|c|}{ LEVEL 2} \\
\hline & Position & $\begin{array}{c}\text { Mean } \\
\text { (sd) }\end{array}$ & $P$ & $\begin{array}{c}\text { Mean } \\
\text { (sd) }\end{array}$ & $P$ \\
\hline \multirow{4}{*}{ General } & $\begin{array}{c}\text { OS } \\
\text { (surgery group) }\end{array}$ & $1.82( \pm 0.39)$ & \multirow[t]{2}{*}{$0.196^{(1)}$} & $4.60( \pm 1.6)$ & \multirow{2}{*}{$0.009^{(7) *}$} \\
\hline & $\begin{array}{c}\text { DS+NDS } \\
\text { (non-surgery group) }\end{array}$ & $2.03( \pm 0.54)$ & & $4.82( \pm 2.0)$ & \\
\hline & $\begin{array}{c}\text { NOS } \\
\text { (surgery group) }\end{array}$ & $2.16( \pm 0.78)$ & \multirow[t]{2}{*}{$0.423^{(2)}$} & $5.12( \pm 2.21)$ & \multirow{2}{*}{$0.792^{(8) *}$} \\
\hline & $\begin{array}{c}\text { DS+NDS } \\
\text { (non-surgery group) }\end{array}$ & $2.03( \pm 0.54)$ & & $4.82( \pm 2.0)$ & \\
\hline \multirow{4}{*}{ Antero/posterior } & $\begin{array}{c}\text { OS } \\
\text { (surgery group) }\end{array}$ & $1.53( \pm 0.31)$ & \multirow{2}{*}{$0.312^{(3)}$} & $3.96( \pm 1.4)$ & \multirow[t]{2}{*}{$0.004^{(9) *}$} \\
\hline & $\begin{array}{c}\text { DS+NDS } \\
\text { (non-surgery group) }\end{array}$ & $1.64( \pm 0.48)$ & & $4.05( \pm 1.6)$ & \\
\hline & $\begin{array}{c}\text { NOS } \\
\text { (surgery group) }\end{array}$ & $1.67( \pm 0.43)$ & \multirow{2}{*}{$0.689^{(4)}$} & $4.32( \pm 2.03)$ & \multirow{2}{*}{$0.922^{(10)}$} \\
\hline & $\begin{array}{c}\text { DS+NDS } \\
\text { (non-surgery group) }\end{array}$ & $1.64( \pm 0.48)$ & & $4.05( \pm 1.6)$ & \\
\hline \multirow{4}{*}{ Medial/lateral } & OS & $1.17( \pm 0.23)$ & \multirow[b]{2}{*}{$0.103^{(5)}$} & $2.59( \pm 0.78)$ & \multirow[b]{2}{*}{$\mathbf{0 . 0 1 0}^{(11)}$} \\
\hline & $\begin{array}{c}\text { DS+NDS } \\
\text { (non-surgery group) }\end{array}$ & $1.33( \pm 0.32)$ & & $2.76( \pm 1.2)$ & \\
\hline & $\begin{array}{c}\text { NOS } \\
\text { (surgery group) }\end{array}$ & $1.51( \pm 0.72)$ & \multirow[b]{2}{*}{$0.148^{(6)}$} & $2.87( \pm 1.02)$ & \multirow[b]{2}{*}{$0.632^{(12)}$} \\
\hline & $\begin{array}{c}\text { DS+NDS } \\
\text { (non-surgery group) }\end{array}$ & $1.33( \pm 0.32)$ & & $2.76( \pm 1.27)$ & \\
\hline
\end{tabular}

[(1) (3) (4) (5) (7) (9) (10)(11) Student's non-paired t test, ${ }^{(2)(6)(8)(12)}$ Mann-Whitney U-test] $* p \leq 0.05$

$\mathrm{OS}=$ operated side; $\mathrm{NOS}=$ non-operated side; $\mathrm{DS}+\mathrm{NDS}=$ dominant and non-dominant sides.

Table 3 - Intergroup comparison of the center of gravity dislocation and postural balance in the Surgery Group (OS and NOS) versus the Sedentary Group (DS and NDS) at stability levels 8 and 2

\begin{tabular}{|c|c|c|c|c|c|}
\hline \multirow[b]{2}{*}{ Index of stability } & \multicolumn{3}{|c|}{ LEVEL 8} & \multicolumn{2}{|c|}{ LEVEL 2} \\
\hline & Position & $\begin{array}{c}\text { Mean } \\
\text { (sd) }\end{array}$ & $P$ & $\begin{array}{c}\text { Mean } \\
\text { (sd) }\end{array}$ & $P$ \\
\hline \multirow{4}{*}{ General } & $\begin{array}{c}\text { OS } \\
\text { (surgery group) }\end{array}$ & $1.82( \pm 0.39)$ & \multirow{2}{*}{$0.255^{(1)}$} & $4.60( \pm 1.6)$ & \multirow{2}{*}{$0.016^{*(7)}$} \\
\hline & $\begin{array}{c}\text { DS+NDS } \\
\text { (sedentary group) }\end{array}$ & $1.75( \pm 0.32)$ & & $3.68( \pm 1.25)$ & \\
\hline & $\begin{array}{c}\text { NOS } \\
\text { (surgery group) }\end{array}$ & $2.16( \pm 0.78)$ & \multirow{2}{*}{$0.009 *(2)$} & $5.12( \pm 2.21)$ & \multirow{2}{*}{$0.009 *(8)$} \\
\hline & $\begin{array}{c}\text { DS+NDS } \\
\text { (sedentary group) }\end{array}$ & $1.75(0.32)$ & & $3.68( \pm 1.25)$ & \\
\hline \multirow{4}{*}{ Antero/posterior } & $\begin{array}{c}\text { OS } \\
\text { (surgery group) }\end{array}$ & $1.53( \pm 0.31)$ & \multirow{2}{*}{$0.120^{(3)}$} & $3.96( \pm 1.46)$ & \multirow{2}{*}{$0.027 *(9)$} \\
\hline & $\begin{array}{c}\text { DS+NDS } \\
\text { (sedentary group) }\end{array}$ & $1.41(0.29)$ & & $3.07( \pm 1.0)$ & \\
\hline & $\begin{array}{c}\text { NOS } \\
\text { (surgery group) }\end{array}$ & $1.67( \pm 0.43)$ & \multirow{2}{*}{$0.004 *(4)$} & $4.32( \pm 2.03)$ & \multirow{2}{*}{$0.014 *(10)$} \\
\hline & $\begin{array}{c}\text { DS+NDS } \\
\text { (sedentary group) }\end{array}$ & $1.41( \pm 0.29)$ & & $3.07( \pm 1.0)$ & \\
\hline \multirow{4}{*}{ Medial/lateral } & $\begin{array}{c}\text { OS } \\
\text { (surgery group) }\end{array}$ & $1.17( \pm 0.23)$ & \multirow{2}{*}{$0.763^{(5)}$} & $2.59( \pm 0.78)$ & \multirow{2}{*}{$0.024 *(11)$} \\
\hline & $\begin{array}{c}\text { DS+NDS } \\
\text { (sedentary group) }\end{array}$ & $1.18( \pm 0.26)$ & & $2.20( \pm 0.78)$ & \\
\hline & $\begin{array}{c}\text { NOS } \\
\text { (surgery group) }\end{array}$ & $1.51( \pm 0.72)$ & \multirow{2}{*}{$0.010 *(6)$} & $2.87( \pm 1.02)$ & \multirow{2}{*}{$0.005 *(12)$} \\
\hline & $\begin{array}{c}\text { DS+NDS } \\
\text { (sedentary group) }\end{array}$ & $1.18( \pm 0.26)$ & & $2.20( \pm 0.78)$ & \\
\hline
\end{tabular}


Table 4 - Intergroup comparison of the center of gravity dislocation and postural balance in the Sedentary Group (DS and NDS) versus the Non-surgery Group (DS and NDS) at stability levels 8 and 2

\begin{tabular}{|c|c|c|c|c|c|}
\hline \multirow[b]{2}{*}{ Index of stability } & \multicolumn{3}{|c|}{ LEVEL 8} & \multicolumn{2}{|c|}{ LEVEL 2} \\
\hline & Position & $\begin{array}{c}\text { Mean } \\
\text { (sd) }\end{array}$ & $P$ & $\begin{array}{c}\text { Mean } \\
\text { (sd) }\end{array}$ & $P$ \\
\hline \multirow{2}{*}{ General } & $\begin{array}{c}\text { DS+NDS } \\
\text { (sedentary group) }\end{array}$ & $1.73(0.33)$ & \multirow[t]{2}{*}{$0.006^{(1)^{*}}$} & $3.75(1.29)$ & \multirow[t]{2}{*}{$0.010^{(4)^{*}}$} \\
\hline & $\begin{array}{c}\text { DS+NDS } \\
\text { (non surgery group) }\end{array}$ & $1.98(0.47)$ & & $4.97(2.24)$ & \\
\hline \multirow{2}{*}{ Antero/posterior } & $\begin{array}{c}\text { DS+NDS } \\
\text { (sedentary group) }\end{array}$ & $1.41(0.31)$ & \multirow[t]{2}{*}{$0.007^{(2)^{*}}$} & $3.16(1.14)$ & \multirow[t]{2}{*}{$0.009^{(5)^{*}}$} \\
\hline & $\begin{array}{c}\text { DS+NDS } \\
\text { ((non surgery group) }\end{array}$ & $1.64(0.42)$ & & $4.22(1.91)$ & \\
\hline \multirow{2}{*}{ Medial/lateral } & $\begin{array}{c}\text { DS+NDS } \\
\text { (sedentary group) }\end{array}$ & $1.15(0.23)$ & \multirow[t]{2}{*}{$0.025^{(3)^{*}}$} & $2.19(0.69)$ & \multirow[t]{2}{*}{$0.015^{(6)^{*}}$} \\
\hline & $\begin{array}{c}\text { DS+NDS } \\
\text { (non surgery group) }\end{array}$ & $1.28(0.28)$ & & $2.79(1.21)$ & \\
\hline
\end{tabular}

$\mathrm{DS}+\mathrm{NDS}=$ dominant side and non-dominant side

and (indirectly) proprioceptive neuromuscular information. This kind of information could be useful during rehabilitation from ACL injuries. The reliability of the balance tests with the BBS was considered satisfactory in previously published studies, which motivated the present study. ${ }^{24,25}$

In this study, when the OS and NOS in the Surgery Group were compared, the operated side was always more stable for all indices of stability at level eight (more stable). Albeit contradictory, this result suggests that the patients have less compensatory mechanisms to maintain the dynamic stability of the operated limb. Such a finding has not been published in other studies that used the force platform. ${ }^{16,17}$ At level two (greater stability), there were no significant differences between the OS and NOS, perhaps because the compensatory mechanisms are not sufficient to support the balance in this situation. This result is in agreement with Henriksson et al. ${ }^{16}$ who used EquiTest Neurocom equipment.

Dominance did not influence the postural balance in the Non-Surgery and Sedentary groups at either level of stability. These results have also been found by Tookuni et al. ${ }^{3}$ using FScan MAT equipment. These findings are very important because they could be used to evaluate rehabilitation results and postural balance deficit.

In comparing the Surgery Group and the Non-surgery Group at level eight, there was no difference, which indicates a good recovery of the operated site. This result is in agreement with Ochi et al., ${ }^{7}$ (somatosensory potential and position sense) and Henriksson et al. ${ }^{16}$ (balance evaluation using Equitest equipment). However, Bonfim et al. ${ }^{17}$ demonstrated a deficit in the operated subjects when compared with a control group using position sense, kinesthesia, latency, and balance (force platform). At level two, for the same comparison (Surgery Group OS and Non- surgery Group), the operated side was more stable. It is important to consider that at level two (greater instability of the equipment), the range of movement of the platform is very extensive and demands more postural adjustments in order to maintain equilibrium..$^{15,24}$ Kinetic and kinematic analyses showed that subjects with ACL reconstruction use different strategies to generate joint torque in squat exercises. ${ }^{26}$ These different motor strategies may influence postural balance. Our data, though contradictory, agree with those authors who consider that surgery continues to affect the functional performance of the joint, even after a period sufficient for the complete re-enervation of the graft. ${ }^{10,17,27,28}$ At level two, the Sedentary Group presented less center of gravity dislocation and better postural balance when compared with the Surgery Group (OS and NOS) and the Non-surgery Group, which is not seen in other studies.

We observed that sensory-motor demand is different in the Sedentary Group. Soccer calls on and stimulates sensory receptors because of the frequent direction, jumping, acceleration and deceleration changes. We expected that soccer players respond better to the balance test, with less dislocation of the center of gravity, but what we observed is a great dislocation of the center of gravity and poor postural balance in the Non-surgery Group. It is possible that the greater dislocation observed is a strategy that helps maintain postural balance even in critical situations. This evaluation does not indicate the speed with which the subjects regain balance, a factor which may be closely related to proprioceptive ability and the maintenance of postural balance. Training these skills with soccer-specific functions can enhance functional limits and joint mobility and may account for the results. BBS evaluation shows that the knees of sedentary individuals and operated athletes are 
rated as more stable than uninjured athletes' knees. These findings may actually suggest that this equipment does not measure postural balance but shows the dislocation of the center of gravity, which is greater in the uninjured athletes. This greater dislocation would be an adaptation of the athlete to the demand of the sporting activity, at the limit of the maintenance of equilibrium through faster and more complex neuromuscular responses. Athletes develop more strategies for maintaining balance, and they are able to shift their center of load in more unstable situations caused by successive dislocations, changes of direction, and the specific activity of carrying the ball.

\section{CONCLUSIONS}

The dislocation of the center of gravity and change in postural balance in sedentary individuals and on the operated limb of Surgery Group are less marked than in the soccer players from the Non Surgery Group and on the nonoperated limbs (Surgery Group).

At the Surgery Group, the dislocation of the center of gravity and the change in postural balance from the operated limb of the soccer players is less marked than in their nonoperated limbs.

\section{REFERENCES}

1. Beard D, Refshauge K. Effects of ACL Reconstruction on proprioception and neuromuscular performance. In: Lephart SM, Fu FH, editors. Proprioception and neuromuscular control in joint stability. Philadelphia: Human Kinetics; 2000. p. 213-24.

2. Riemann BL, Guskiewicz KM. Contribution of the peripheral somatosensory system to balance and postural. In: Lephart SM, Fu FH, editors. Proprioception and neuromuscular control in joint stability. USA: Human Kinetics; 2000. p. 37-51.

3. Tookuni KS, Neto RB, Pereira CAM, Souza DR, Greve JMD, Ayala AD. Análise comparativa do controle postural de pacientes com e sem lesão do ligamento cruzado anterior do joelho. Acta Ortop Bras. 2005;13:1159 .

4. Barrack RL, Munn BG. Effects of Knee ligament Injury and reconstruction on proprioception. In: Lephart $\mathrm{SM}, \mathrm{Fu} \mathrm{FH}$, editors. Proprioception and neuromuscular control in joint stability. Philadelphia: Human Kinetics; 2000. p. 197-212.

5. Battistella LR, Shinzato GT. Retorno à atividade física pós -tratamento do aparelho locomotor. In: Ghoroyeb N, Barros T. O Exercício: por tração fisiológica avaliação médica, aspectos especiais e preventivos. São Paulo: Atheneu; 1999. p. 295-304.

6. Voight M, Blackburn T. Treinamento e testes de propriocepção e equilíbrio após a lesão. In: Ellenbecker TS. Reabilitação dos ligamentos do joelho. São Paulo: Manole; 2002. p. 401-26.

7. Ochi M, Iwasa J, Uchio Y, Adachi N, Sumen Y. The regeneration of sensory neurones in the reconstruction of the anterior cruciate ligament. J. Bone Joint Surg Br. 1999;81:902-06.

8. Bonfim TR, Paccola CAJ. Propriocepção após a reconstrução do ligamento cruzado anterior usando ligamento patelar homólogo e autólogo. Rev. Bras Ortop. 2000;35:194-201.

9. Fremerey RW, Lobenhoffer P, Zeichen J, Skutek M, Bosch U, Tscherne $H$. Proprioception after rehabilitation and reconstruction in knees with deficiency of the anterior cruciate ligament. J Bone Joint Surg Br. 2000;82:801-6.

10. Risberg MA, Beynnon BD, Peura GD. Proprioception after anterior cruciate ligament reconstruction with and without bracing. Knee Surg. Sports Traumatol Arthrosc. 1999; 7:303-9.
11. Johansson H, Sjölander P, Sojka P. A sensory role for the cruciate ligaments. Clin Orthop Relat Res. 1991;(268):161-78.

12. Pitman ML, Nainzadeh N, Menche D, Gasalberti R, Song EK. The Intraoperative evaluation of the neurosensory function of the anterior cruciate ligament in humans using somatosensory evoked potentials. J Arthrosc. 1992;8:442-7.

13. Beard DJ, Kyberd PJ, Fergusson CM, Doodd CA. Proprioception after rupture of the anterior cruciate ligament. An objective indication of the need for surgery?. J Bone Joint Surg Br. 1993;75:311-5.

14. Barrack RL, Lund PJ, Munn BG, Wink C, Happel L. Evidence of reinnervation of free patellar tendon autograft used for anterior cruciate ligament reconstruction. Am J Sports Med.1997;25:196-202.

15. Ageberg E, Zätterström R, Moritz U, Fridén I. Influence of supervised and nonsupervised training on postural control after an acute anterior cruciate ligament rupture: A three-year longitudinal prospective study. J. Orthop Sports Phys Ther. 2001;31:632-44.

16. Henriksson M, Ledin T, Good L. Postural control after anterior cruciate ligament reconstruction and functional rehabilitation. Am J Sports Med. 2001;29:359-66.

17. Bonfim TR, Pacolla CAJ, Barela JA. Proprioceptive and behavior impairments in individuals with anterior cruciate ligament reconstructed knees. Arch Phys Med Rehabil. 2003;84:1217-23.

18. Kejonen P, Kauranen K, Vanharanta $\mathrm{H}$. The relationship between anthopometric factors and body-balancing movements in postural balance. Arch Phys Med Rehabil. 2003;84:17-22.

19. Palmieri RM, Ingersoll CI, Cordova ML, Kinzey SJ, Stone, MB, Krause A. The effect of a simulated knee joint effusion on postural control in healthy subjects. Arch Phys Med Rehabil. 2003;84:1076-9.

20. Beynnon BD, Renström PA, Konradsen L, Emlqvist LG, Gotlieb D, Dirks M. Validation of techniques to measure knee proprioception. In Lephart SM, Fu FH. Proprioception and neuromuscular control in joint stability. USA: Human Kinestics; 2000. p. 127-38.

21. Cachupe WJC, Shifflett B, Kahanov L, Wughalter EH. Reliability of Biodex Balance System measures. Measurem Phys Educ Exerc Sci. 2001;5:97-108. 
22. Perrin DH, Shultz SJ. Models for Clinical Research Involving Proprioception and neuromuscular control. In: Lephart SM, Fu FH. Proprioception and neuromuscular control in joint stability. USA: Human kinestics; 2000. p.349-62.

23. Arnold BL, Schmitz RJ. Examination of balance measures produced by the Biodex Stability System. J Athl Train. 1998;33:323-27.

24. Hinmam MR. Factors affecting reliability of the Biodex Balance System: a summary of four studies. J Sport Rehabil. 2000;9:240-52.

25. Schmitz RJ, Arnold BL. Intertester and Intratester reliability of a dinamic balance protocol using the Biodex Balance System. J Sport Rehabil. 1998;7:95-101
26. Salem GJ, Salinas R, Harding V. Bilateral kinematic and kinetic analysis of the squat exercise after anterior cruciate ligament reconstruction. Arch Phys Med Rehabil. 2003; 84:1211-6.

27. Iwasa J, Ochi M, Adachi N, Tobita M, Katsube K, Uchio Y. Proprioceptive improvement in knees with anterior cruciate ligament reconstruction. Clin Orthop Relat Res. 2000;381:168-76.

28. Barrack, RL, Skinner HB, Buckley SL. Proprioception in the anterior cruciate deficient knee. Am J Sports Med. 1989;17:1-6. 